\title{
Immunohistochemical study on the distribution of $\beta$-defensin 1 and $\beta$-defensin 2 throughout the respiratory tract of healthy rats
}

\author{
Natsumi MASUDA ${ }^{1)}$, Youhei MANTANI ${ }^{1)}$, Hideto YUASA ${ }^{1)}$, Chiaki YOSHITOMI ${ }^{1}$, \\ Masaya ARAI ${ }^{1}$, Miho NISHIDA ${ }^{1)}$, Wang-Mei Q(2), Junichi KAWANO ${ }^{3)}$, \\ Toshifumi YOKOYAMA ${ }^{4)}$, Nobuhiko HOSHI ${ }^{4)}$ and Hiroshi KITAGAWA ${ }^{1) *}$ \\ 1)Laboratory of Histophysiology, Department of Bioresource Science, Graduate School of Agricultural Science, \\ Kobe University, 1-1 Rokkodai-cho, Nada-ku, Kobe, Hyogo 657-8501, Japan \\ ${ }^{2)}$ Department of Basic Veterinary Medicine, College of Veterinary Medicine, Inner Mongolia Agricultural \\ University, 306 Zhaowuda Road, Huhhot, Inner Mongolia 010018, P. R. China \\ 3) Laboratory of Microbiology and Immunology, Department of Bioresource Science, Graduate School of \\ Agricultural Science, Kobe University, 1-1 Rokkodai-cho, Nada-ku, Kobe, Hyogo 657-8501, Japan \\ ${ }^{4)}$ Laboratory of Molecular Morphology, Department of Bioresource Science, Graduate School of Agricultural \\ Science, Kobe University, 1-1 Rokkodai-cho, Nada-ku, Kobe, Hyogo 657-8501, Japan
}

J. Vet. Med. Sci.

80(3): 395-404, 2018

doi: 10.1292/jvms.17-0686

Received: 15 December 2017 Accepted: 24 December 2017 Published online in J-STAGE: 1 January 2018
ABSTRACT. The distributions of $\beta$-defensin 1 and 2 in secretory host defense system throughout respiratory tract of healthy rats were immunohistochemically investigated. In the nasal epithelium, a large number of non-ciliated and non-microvillous cells (NCs) were immunopositive for both $\beta$-defensin 1 and 2, whereas a small number of goblet cells (GCs) were immunopositive only for $\beta$-defensin 1. Beta-defensin 2-immunopositive GCs were few. In the nasal glands, a small number of acinar cells and a large number of ductal epithelial cells were immunopositive for both $\beta$-defensins. In the laryngeal and tracheal epithelia, a very few NCs and GCs were immunopositive for both $\beta$-defensins. In laryngeal and tracheal glands, a very few acinar cells and a large number of ductal epithelial cells were immunopositive for both $\beta$-defensins. In the extra-pulmonary bronchus, a small number of NCs were immunopositive for both $\beta$-defensins. A small number of GCs were immunopositive for $\beta$-defensin 1, whereas few GCs were immunopositive for $\beta$-defensin 2. From the intra-pulmonary bronchus to alveoli, a very few or no epithelial cells were immunopositive for both $\beta$-defensins. In the mucus and periciliary layers, $\beta$-defensin 1 was detected from the nose to the extra-pulmonary bronchus, whereas $\beta$-defensin 2 was weakly detected only in the nose and the larynx. These findings suggest that the secretory sources of $\beta$-defensin 1 and 2 are mainly distributed in the nasal mucosa and gradually decrease toward the caudal airway in healthy rats.

KEY WORDS: bactericidal substance, host defense, mucus layer, respiratory organ, secretory cell

The cyclic inhalation of outside air into the respiratory tract introduces microorganisms and other foreign substances [23, 48]. Large particulates generally deposit on the surfaces of cranial respiratory mucosa [14, 23, 37], whereas minute particulates, such as bacteria, deposit on those of entire respiratory tract $[23,37]$. The mucus and periciliary layers are located on the nose and the tract from the larynx to extra-pulmonary bronchus $[30,50]$, and inhaled particulates adhere to either layers. The mucus and periciliary fluids are transported toward the pharynx by the beating of cilia of epithelial cells [31] and are finally swallowed into the alimentary tract $[19,31]$. However, in the most caudal portion of the airway, the alveolus, inhaled particles adhere to the serous layer (corresponding to the periciliary layer in other respiratory portions) and are engulfed by alveolar macrophages [42].

The deposited bacteria are affected by various bactericidal substances, such as lysozyme, secretory phospholipase A2 (sPLA2) and defensins that are contained in the nasal or bronchi-alveolar lavage fluids [44]. Lysozyme and sPLA2, which have wide antimicrobial spectra $[13,18,35,47]$, are contained in secretions in various lavage fluids from humans $[2,9,10]$. A previous immunohistochemical study clarified the distributions of lysozyme- and sPLA2-secreting cells of the respiratory tract of healthy rats $[30]$. 
Defensins are classified into three types according to their structure: $\alpha$-defensins, $\beta$-defensins and $\theta$-defensins. There are 39 $\beta$-defensin genes in humans, 43 in rats, 43 in dogs and 52 in mice [34]. In general, $\beta$-defensin proteins are named as the products of $\beta$-defensin genes that were originally numbered sequentially on discovery, except for $\beta$-defensin 2 protein, which was shown to be encoded by the gene Defb 4 in rat and mouse $[34,40]$. Therefore, the $\beta$-defensin encoded by Defb 4 is designated as $\beta$-defensin 2 in this report, as in the past. The defensins also have a wide antimicrobial spectrum, with the capacity to kill Gram-positive and -negative bacteria [4], viruses [43] and fungi [12], although they preferentially attack Gram-negative over Gram-positive bacteria $[20,21,40]$. Their bactericidal activity depends on the formation of multimers of defensin molecules in the bacterial membranes and the acceleration of permeability through the bacterial membranes [24]. Beta-defensin 1 has been detected in nasal lavage fluids [8] and broncho-alveolar lavage fluids [1, 26]. Beta-defensin 2 has been detected in nasal lavage fluids [11] and broncho-alveolar lavage fluids [26] from healthy humans. Beta-defensin $1 \mathrm{mRNA}$ has also been detected in the bronchus of humans [41], in the nose, trachea and large bronchioles of mice [3], and in the trachea of rats [27] by in situ hybridization. Beta-defensin 2 mRNA has been detected in the bronchus of humans [41] and granular alveolar cells of rats [27]. However, the detailed distribution of secretory cells of these $\beta$-defensins throughout the respiratory tract has not been clarified in vivo. In this study, therefore, we investigated the detailed distribution of the secretory sources and secretory products of $\beta$-defensin 1 and 2 throughout the respiratory tract of healthy rats.

\section{MATERIALS AND METHODS}

\section{Animals}

Thirteen specific-pathogen-free male Wistar rats aged 7 weeks and derived from different mothers (Japan SLC Inc., Hamamatsu, Japan) were maintained under specific-pathogen-free conditions in individual ventilated cages (Sealsafe PLUS; Tecniplast S.p.A, Buguggiate, Italy) with controlled temperature $\left(23 \pm 1^{\circ} \mathrm{C}\right)$ and humidity $(50 \%)$ under a 12-hr light/dark cycle at the Life-Science Laboratory of Kobe University. All animals were permitted free access to water and food (Lab R-A2; Japan SLC Inc.). Clinical and pathological examinations in all animals confirmed no sign of disorder. Experiments were approved by the Institutional Animal Care and Use Committee (permission number: 25-06-01) and were carried out according to the Kobe University Animal Experimentation Regulations.

\section{Tissue preparation}

All rats were euthanized with an intraperitoneally injected overdose of pentobarbital sodium (Kyoritsu Seiyaku Corp., Tokyo, Japan).

To identify secretory sources of $\beta$-defensin 1 and $\beta$-defensin 2,8 rats were transcardially perfused with $4 \%$ paraformaldehyde (PFA) in $0.1 \mathrm{M}$ phosphate buffer at $38^{\circ} \mathrm{C}$. After perfusion, the respiratory region of the nasal mucosa and larynx, trachea, extrapulmonary bronchus and lung with intra-pulmonary bronchus were immediately removed and cut into small blocks. All tissue blocks were immersion-fixed in $4 \%$ PFA for $6 \mathrm{hr}$ at $4{ }^{\circ} \mathrm{C}$. The blocks were dehydrated and embedded in paraffin with routine methods.

To determine the localization of $\beta$-defensin 1 and $\beta$-defensin 2 in both the mucus layer and periciliary layer, the nasal mucosa, larynx, trachea and extra-pulmonary bronchus were removed from 5 rats after euthanasia. The tissues were cut into small blocks and immediately and gently immersed in Carnoy's fluid with minimal movement of the liquid for 5 min at room temperature (r.t.). After fixation, the tissue blocks were dehydrated and embedded in paraffin.

Four $\mu \mathrm{m}$-thick sections were cut and mounted on slide glasses precoated with $0.2 \% 3$-aminopropyltriethoxysilane (Shin-Etsu Chemical Co., Tokyo, Japan) and stored at $4^{\circ} \mathrm{C}$ until use.

\section{Immunohistochemistry}

Antigens were detected using the indirect method of enzyme immunohistochemistry. Briefly, after deparaffinization, sections of only PFA-fixed tissues were incubated in $0.06 \mu \mathrm{g} / \mathrm{ml}$ Proteinase K (Sigma-Aldrich Inc., St. Louis, MO, U.S.A.) solution for 20 $\mathrm{min}$ at $37^{\circ} \mathrm{C}$ for antigen retrieval, and then rinsed with $0.05 \%$ Tween-added $0.01 \mathrm{M}$ phosphate buffered saline (TPBS; $\mathrm{pH} 7.4$ ). Both antigen-retrieved sections of PFA-fixed tissues and deparaffinized sections of Carnoy's fluid-fixed tissues were immersed in absolute methanol and $0.5 \% \mathrm{H}_{2} \mathrm{O}_{2}$ each for $30 \mathrm{~min}$ to remove endogenous peroxidase activity. Then, three rinses with TPBS were performed after all preparation steps to remove any reagent residues. Following blocking with Blocking One Histo (Nacalai Tesque Inc., Kyoto, Japan) for $1 \mathrm{hr}$ at r.t., the sections were reacted with anti $\beta$-defensin 1 goat IgG (diluted at 1:200 for PFA-fixed tissue, 1:50 for Carnoy's fluid-fixed tissue) or anti $\beta$-defensin 2 goat IgG (diluted at 1:200 for PFA-fixed tissue, 1:400 for Carnoy's fluidfixed tissue) (Santa Cruz Biotechnology Inc., Santa Cruz, CA, U.S.A.) for $18 \mathrm{hr}$ at $6^{\circ} \mathrm{C}$. The antibody specificity for rat $\beta$-defensin 1 and 2 is described in the manufacturer's specification forms ( $\beta$-defensin 1 , sc-10851; $\beta$-defensin 2 , sc-10856), respectively. Then, the sections were incubated with horseradish peroxidase-conjugated anti goat IgG donkey IgG (diluted at 1:200; 705-035-147, Jackson Immuno Research Inc., West Grove, PA, U.S.A.) for $1 \mathrm{hr}$ at r.t. After rinsing with TPBS, the sections were incubated with 3,3'-diaminobenzidine tetrahydrochloride (Dojindo Lab., Mashiki, Japan) containing $0.03 \% \mathrm{H}_{2} \mathrm{O}_{2}$, and were counterstained with hematoxylin. Control sections were incubated with TPBS or non-immunized goat IgG instead of primary antibodies.

\section{Polysaccharide staining}

Periodic acid Schiff (PAS) reaction was conducted using Carnoy's fluid-fixed tissues to confirm the preservation of the mucus layer. 


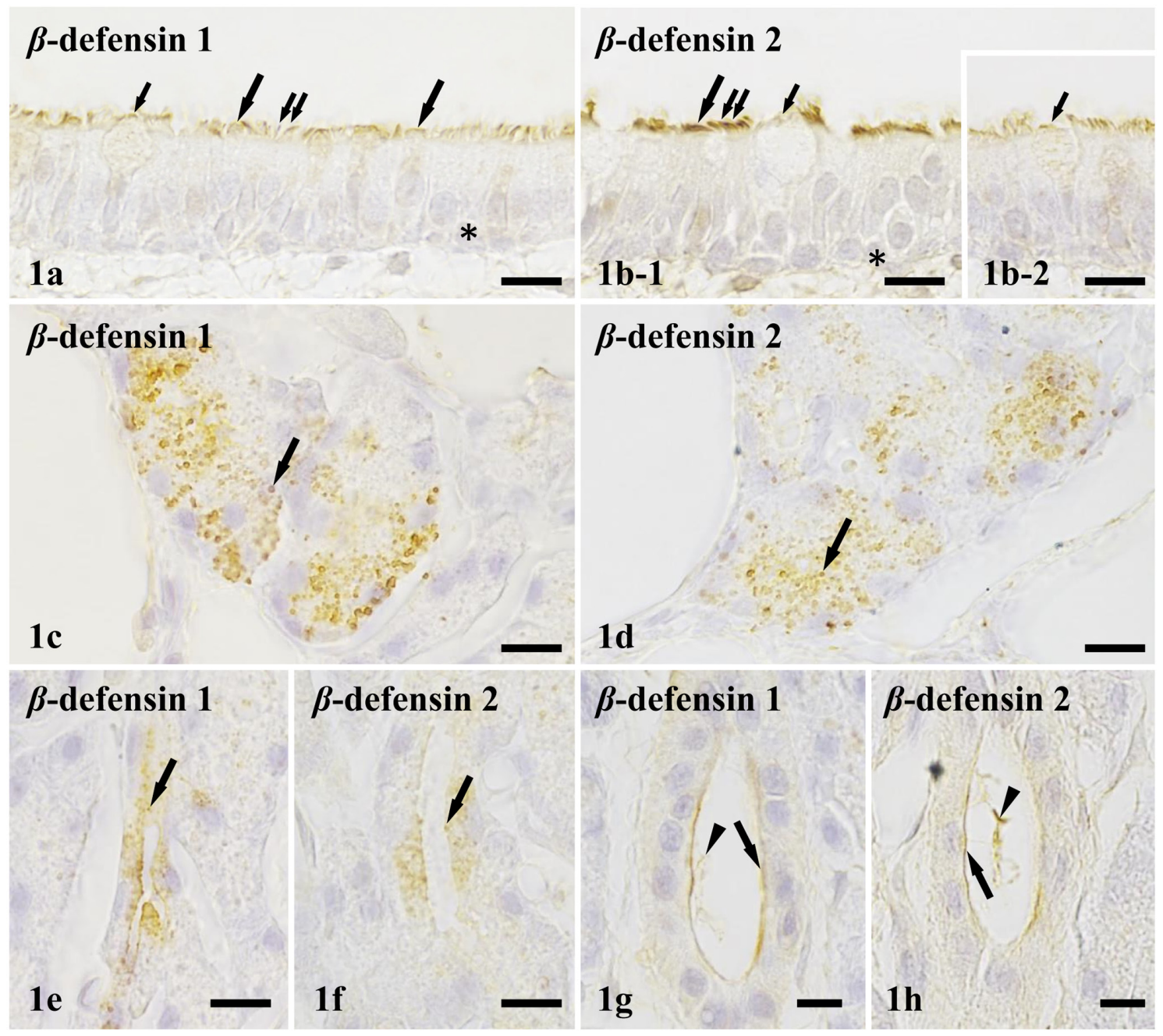

Fig. 1. Localization of $\beta$-defensin 1 and 2 in the nasal mucosa. In the nasal epithelium, $\beta$-defensin 1 and 2 are immunopositive in NCs (large arrows in a and b-1) and cilia of ciliated epithelial cells (double arrows in a and b-1). GCs are weakly immunopositive for $\beta$-defensin 1 and immunonegative for $\beta$-defensin 2 (small arrows in a and b-1), but rare GC weakly immunopositive for $\beta$-defensin 2 is presented in the insertion figure (small arrow in b-2). All basal epithelial cells are immunonegative (asterisks in a and b-1). In the nasal glands, secretory granules of serous acinar cells (arrows in $\mathrm{c}$ and d) and intercalated ducts (arrows in e and f), the most apical cytoplasm of epithelial cells of the exocrine ducts (arrows in $\mathrm{g}$ and $\mathrm{h}$ ) and the luminal contents of the nasal glands (arrowheads in $\mathrm{g}$ and $\mathrm{h}$ ) are immunopositive for both $\beta$-defensins. Bar=10 $\mu \mathrm{m}$.

\section{RESULTS}

\section{Nasal mucosa}

In the nasal epithelium, ciliated epithelial cells made up the largest population, whereas the populations of non-ciliated and non-microvillous epithelial cells (NCs) and goblet cells (GCs) were small. The apical cytoplasms of a large number of NCs were immunopositive for $\beta$-defensin 1 and $\beta$-defensin 2 . The secretory granules of a small number of GCs were immunopositive for $\beta$-defensin 1, whereas few GCs were immunopositive for $\beta$-defensin 2 . Beta-defensin 1 and $\beta$-defensin 2 were detected on the tips or the entire length of cilia of a large number of ciliated epithelial cells. The basal epithelial cells were immunonegative for both $\beta$-defensins (Fig. 1a and 1b).

The nasal glands are composed of serous acini, intercalated ducts and excretory ducts. The secretory granules in a small number of serous acinar cells and a large number of epithelial cells of intercalated ducts were immunopositive for $\beta$-defensin 1 and $\beta$-defensin 2 (Fig. 1c-f). Immunopositivities for both $\beta$-defensins were also detected on the apical cytoplasms of most epithelial cells of excretory ducts and in the luminal secretory products, which are probably secretion of acinar cells and epithelial cells of excretory ducts (Fig. $1 \mathrm{~g}$ and $1 \mathrm{~h}$ ).

\section{Laryngeal mucosa}

In the laryngeal epithelium, NCs made up the largest cell population, whereas the population of ciliated epithelial cells, GCs and microvillous epithelial cells were small. The cytoplasms of a very few NCs and GCs were immunopositive for $\beta$-defensin 1 


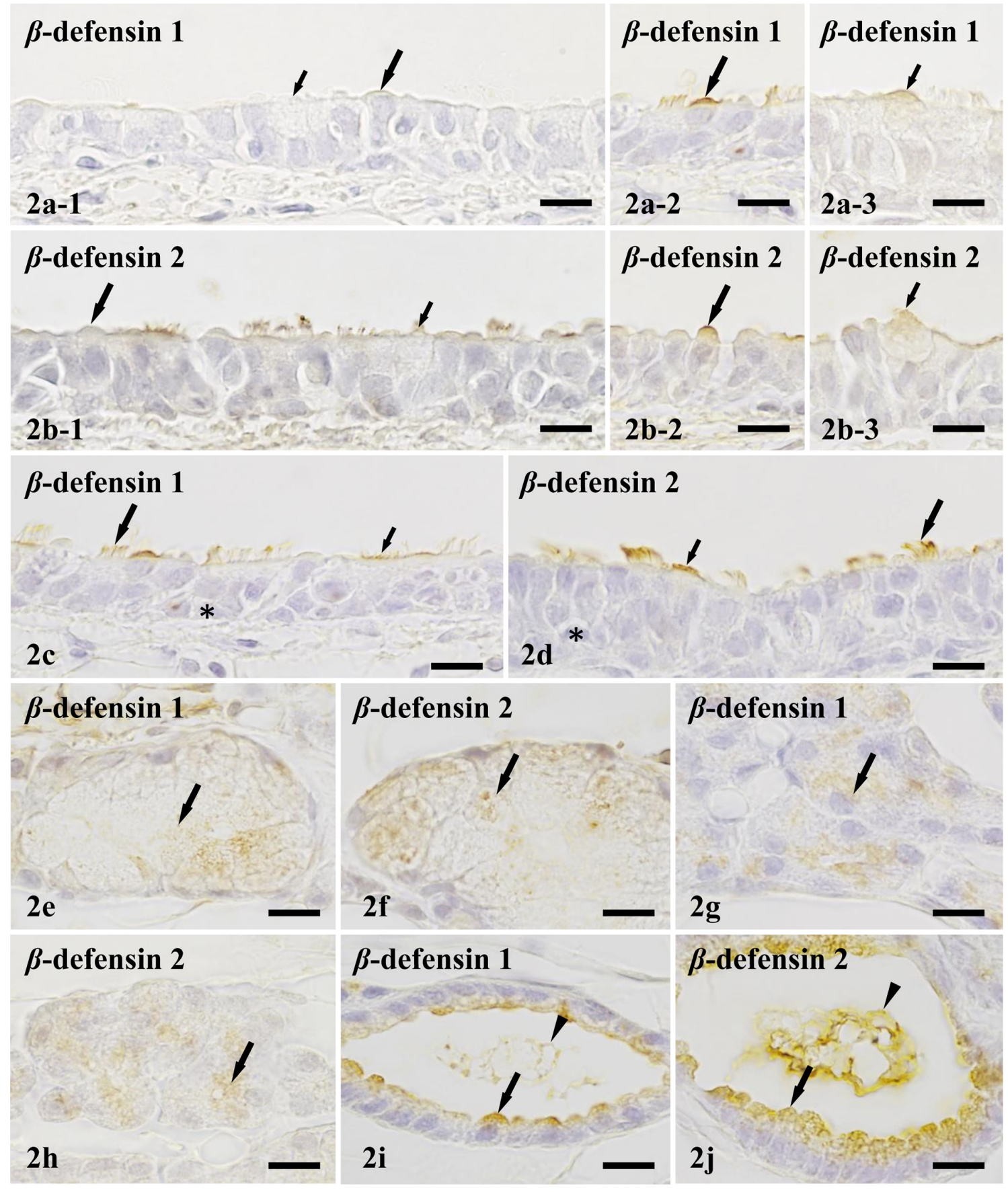

Fig. 2. Localization of $\beta$-defensin 1 and 2 in the laryngeal mucosa. In the laryngeal epithelium, $\beta$-defensin 1 and 2 are immunonegative in NCs (large arrows in a-1 and b-1), GC (small arrows in a-1 and b-1) and basal epithelial cells (asterisks in c and d), and are immunopositive in cilia of ciliated epithelial cells (large arrows in c and d) and striated border of microvillous epithelial cells (small arrows in c and d). The rare NCs (arrows in a-2 and b-2) and GCs (arrows in a-3 and b-3) immunopositive for $\beta$-defensin 1 or 2 are also present. In the laryngeal glands, secretory granules of mucous (arrows in e and $\mathrm{f}$ ) and serous acinar cells (arrows in $\mathrm{g}$ and $\mathrm{h}$ ), epithelial cells of glandular ducts (arrows in $\mathrm{i}$ and $\mathrm{j}$ ) and luminal contents in glandular ducts (arrowheads in i and j) are immunopositive for both $\beta$-defensins. Bar $=10 \mu \mathrm{m}$.

and $\beta$-defensin 2 (Fig. 2a and 2b). Immunopositivities for $\beta$-defensin 1 and $\beta$-defensin 2 were also detected on the tips or the entire length of both the cilia of a large number of ciliated epithelial cells and the striated borders of microvillous cells (Fig. 2c and $2 \mathrm{~d}$ ). No immunopositivities for $\beta$-defensin 1 and $\beta$-defensin 2 were detected in the basal epithelial cells (Fig. 2c and 2d).

The laryngeal glands are composed of mucus and serous acini and excretory ducts. Both $\beta$-defensins were immunopositive in the secretory granules of a very few mucus and serous acinar cells and the apical cytoplasms of a large number of epithelial cells of excretory ducts and the luminal contents, which are probably secretion of acinar cells and epithelial cells of excretory ducts, were immunopositive for both $\beta$-defensins (Fig. 2e-j). 


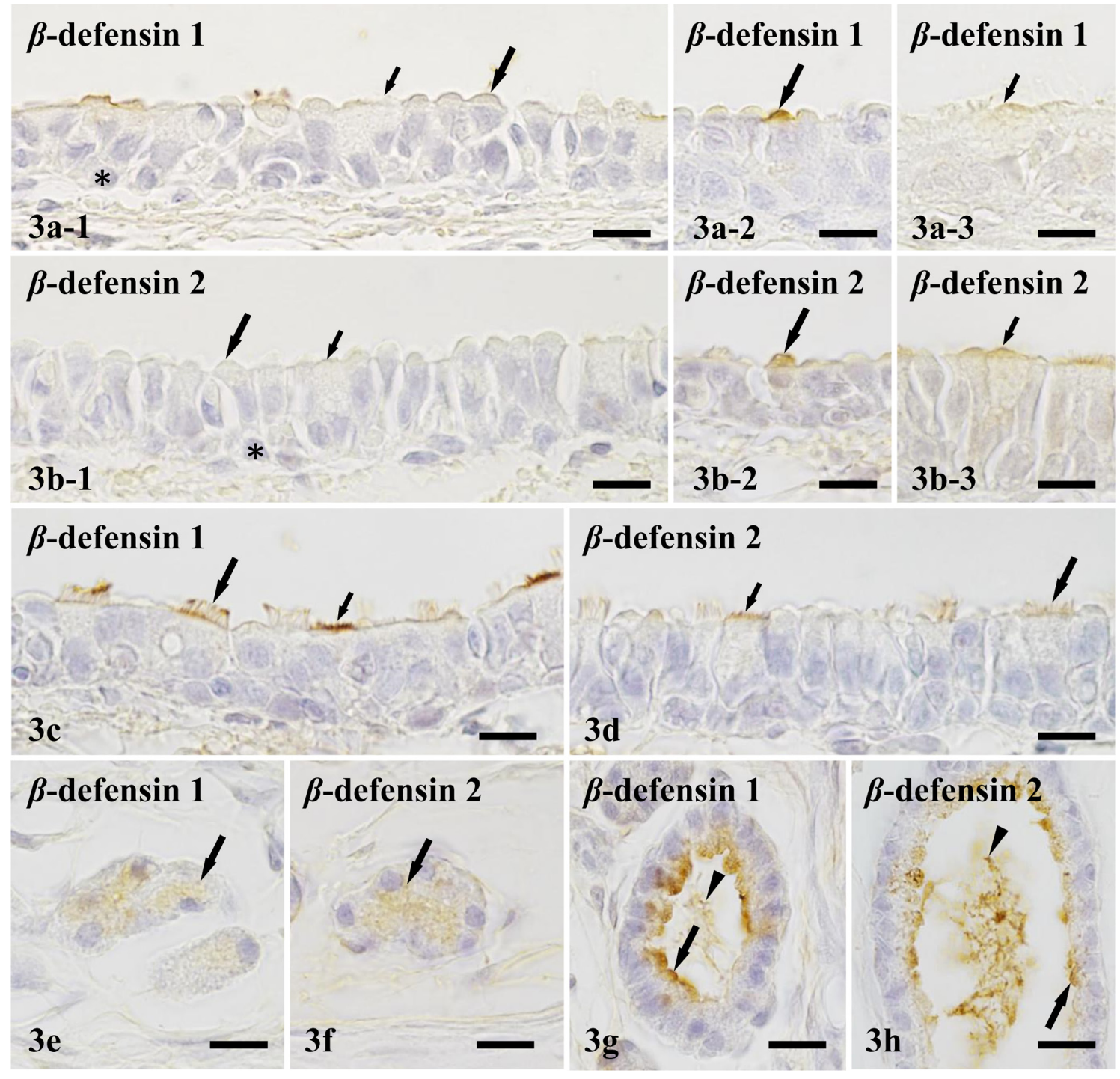

Fig. 3. Localization of $\beta$-defensin 1 and 2 in the tracheal mucosa. In the tracheal epithelium, the NCs (large arrows in a-1 and b-1), GC (small arrows in a-1 and b-1) and basal epithelial cells (asterisks in a- 1 and b-1) are immunonegative for $\beta$-defensin 1 and 2 , and the cilia of ciliated epithelial cells (large arrows in $\mathrm{c}$ and d) and striated border of microvillous epithelial cells (small arrows in $\mathrm{c}$ and d) are immunopositive for both $\beta$-defensins. Rare NCs (arrows in a-2 and b-2) and GCs (arrows in a-3 and b-3) immunopositive for both $\beta$-defensins are also present. In tracheal glands, secretory granules of serous acinar cells (arrows in e and f), epithelial cells of glandular ducts (arrows in $g$ and $h$ ) and luminal contents in the glandular ducts (arrowheads in $\mathrm{g}$ and $\mathrm{h}$ ) are immunopositive for both $\beta$-defensins. Bar=10 $\mu \mathrm{m}$.

\section{Tracheal mucosa}

In the tracheal epithelium, NCs were a dominant cell population, whereas the populations of GCs, ciliated epithelial cells and microvillous epithelial cells were small. A very few NCs and GCs were immunopositive for $\beta$-defensin 1 and $\beta$-defensin 2 (Fig. 3a and $3 \mathrm{~b}$ ). Immunopositivities for both $\beta$-defensins were detected on the tips or the entire length of both the cilia of a large number of ciliated epithelial cells and the striated borders of microvillous cells (Fig. 3c and 3d). Basal epithelial cells were immunonegative (Fig. 3c and 3d).

The tracheal glands are composed of serous acini and excretory ducts. The secretory granules of a very few serous acinar cells were immunopositive for $\beta$-defensin 1 and $\beta$-defensin 2 (Fig. 3e and 3f). The cytoplasms of a large number of epithelial cells of excretory ducts and the luminal contents, which are probably secretion of acinar cells and epithelial cells of excretory ducts, were immunopositive for both $\beta$-defensins (Fig. $3 \mathrm{~g}$ and $3 \mathrm{~h}$ ).

\section{Extra- and intra-pulmonary bronchial mucosae}

In the extra- and intra-pulmonary bronchial epithelium, NCs made up the largest population, whereas the populations of GCs, ciliated epithelial cells and microvillous epithelial cells were small. A small number of NCs were immunopositive for $\beta$-defensin 1 and $\beta$-defensin 2 in the extra-pulmonary bronchial epithelium, whereas a very few NCs were immunopositive for both $\beta$-defensins 


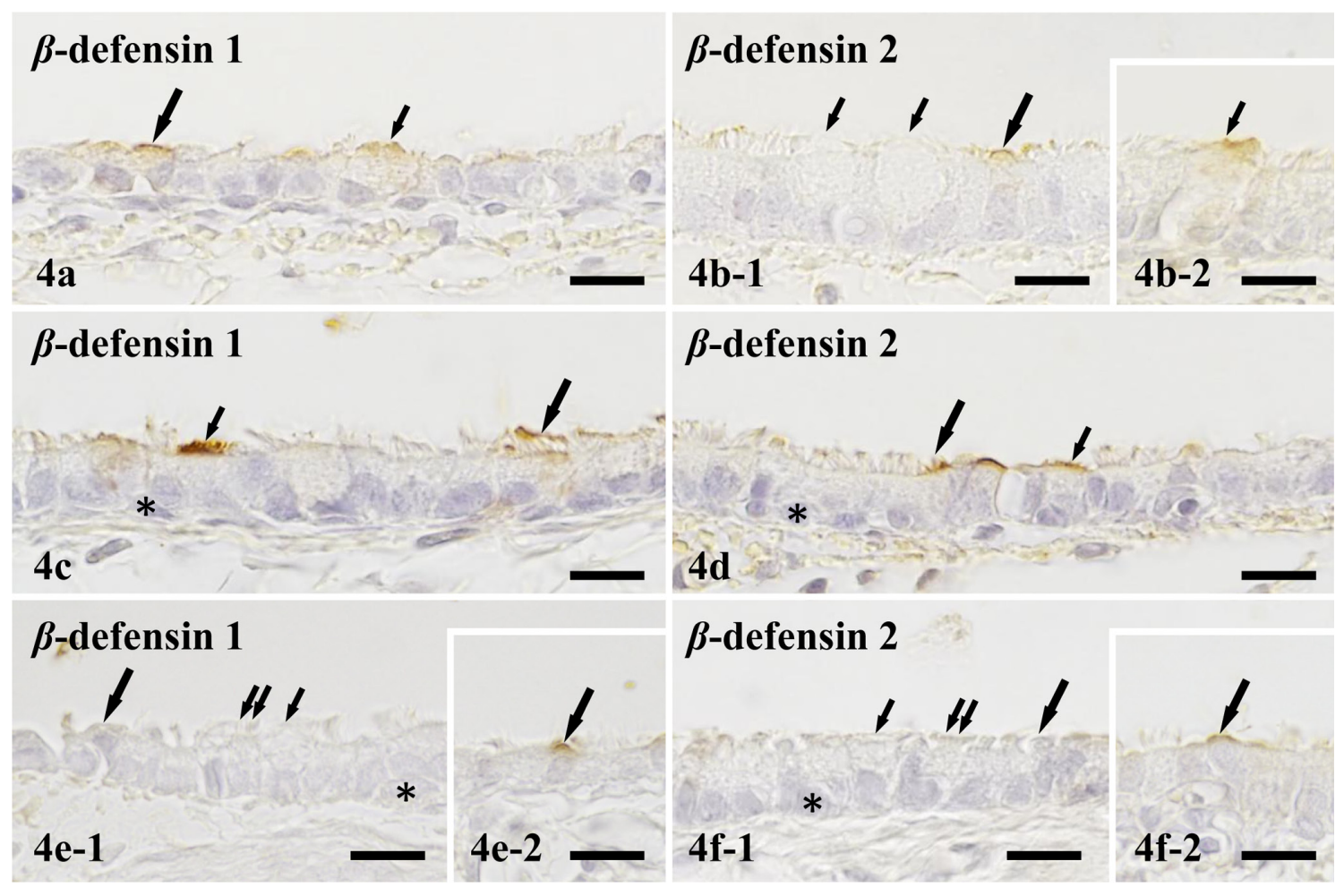

Fig. 4. Localization of $\beta$-defensin 1 and 2 in the extra- and intra-pulmonary mucosae. In the extra-pulmonary bronchial epithelium, $\beta$-defensin 1 and 2 are immunopositive in NCs (large arrows in a and b-1), cilia of ciliated epithelial cells (large arrows in c and d) and striated border of microvillous cells (small arrows in $\mathrm{c}$ and d). GCs (small arrows in a and b-1) are immunopositive for $\beta$-defensin 1 and immunonegative for $\beta$-defensin 2, but rare GC immunopositive for $\beta$-defensin 2 presents in the insertion figure (small arrow in b-2). In intra-pulmonary bronchial epithelium, NCs (large arrows in e-1 and f-1), GCs (small arrows in e-1 and f-1) and ciliated epithelial cells (double arrows in e-1 and f-1) are immunonegative for both $\beta$-defensins. Rare NCs (large arrows in e-2 and f-2) are immunopositive for both $\beta$-defensins as shown in the inset. $\mathrm{Bar}=10 \mu \mathrm{m}$.

in the intra-pulmonary bronchial epithelium. In the extra-pulmonary bronchial epithelium, secretory granules of a small number of GCs were immunopositive for $\beta$-defensin 1 , whereas few GCs were immunopositive for $\beta$-defensin 2 . In the intra-pulmonary bronchial epithelium, no immunopositivities were detected in GCs. Immunopositivities for $\beta$-defensin 1 and $\beta$-defensin 2 were detected on the tips or the entire length of a small number of cilia of ciliated epithelial cells and striated borders of microvillous cells in the extra-pulmonary bronchial epithelium. But cilia of the ciliated epithelial cells were immunonegative for both $\beta$-defensins, and microvillous epithelial cells were not present in the intra-pulmonary bronchial epithelium. Basal epithelial cells in the both bronchial epithelia were immunonegative for both $\beta$-defensins (Fig. $4 \mathrm{a}-\mathrm{f}$ ). In the caudal portion of the extra-pulmonary bronchus, no exocrine glands were found.

\section{Bronchiolar epithelium}

The cytoplasms of NCs, ciliated epithelial cells and Clara cells in the bronchiole were immunonegative for $\beta$-defensin 1 and $\beta$-defensin 2 (Fig. 5a and 5b).

\section{Alveolar epithelium}

In the alveolar epithelium, $\beta$-defensin 1 was not detected in granular alveolar cells, whereas the cytoplasms of few granular alveolar cells were immunopositive for $\beta$-defensin 2 . Neither $\beta$-defensin was detected in either squamous alveolar cells or alveolar macrophages (Fig. 6a and 6b).

\section{Mucus layer and periciliary layer on the epithelial cells}

From specimens with Carnoy's fluid fixation, PAS-reaction clearly identified the mucus layer as a positive line (Fig. 7a-d), which anatomically corresponded with the level of the cilia tips. Beta-defensin 1 was detected in a small part of the mucus layer and the periciliary layer from the nasal to extra-pulmonary bronchial epithelium. The immunopositivity of $\beta$-defensin 1 , especially in the mucus layer, was the strongest in the nose and decreased toward the distal portion of the respiratory tract (Fig. 7e-h). Beta-defensin 2 was weakly detected in only a small portion of the mucus layer and periciliary layer in the nasal and laryngeal epithelium, (Fig. 7i and 7j), but was undetectable in either layer in the tracheal and extra-pulmonary bronchial epithelia (Fig. 7k and 71 ). 


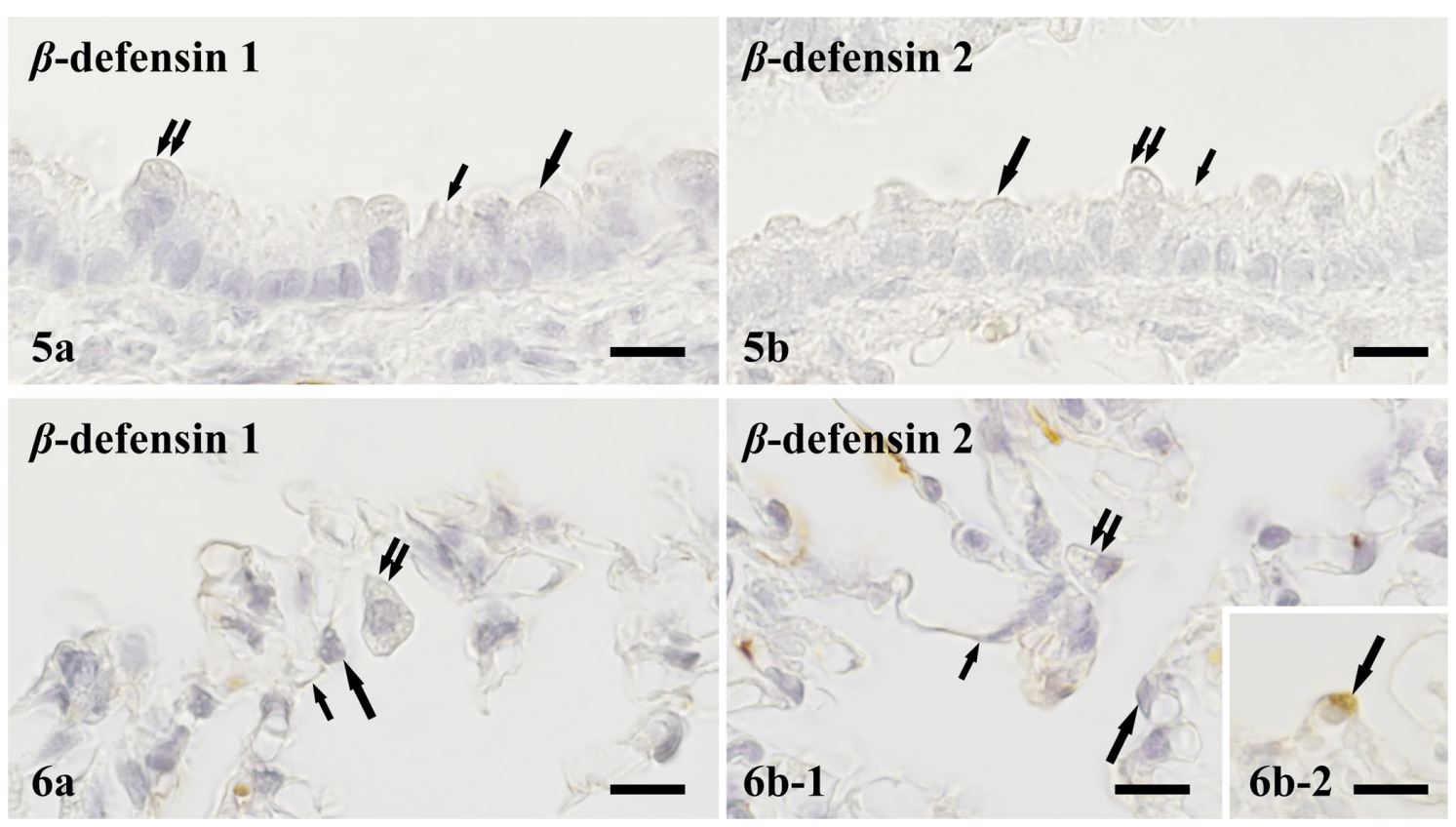

Fig. 5. Localization of $\beta$-defensin 1 and 2 in the bronchiolar mucosa. Beta-defensin 1 and 2 are immunonegative in NCs (large arrows in a and b), ciliated epithelial cells (small arrows in a and b) and Clara cells (double arrows in a and b). Bar $=10 \mu \mathrm{m}$.

Fig. 6. Localization of $\beta$-defensin 1 and 2 in the alveoli. Beta-defensin 1 and 2 are immunonegative in granular alveolar cell (large arrows in a and b-1), squamous alveolar cell (small arrows in a and b-1) and alveolar macrophage (double arrows in a and b-1). Rare granular alveolar cell is immunopositive for $\beta$-defensin 2, as shown in the inset (arrow in b-2). Bar=10 $\mu \mathrm{m}$.

\section{Negative controls}

In the negative control using normal goat IgG instead of the primary antibodies, positive reactions were undetected in specimens with PFA fixation, whereas faint and homogenous immunopositive reactions were detected only in the cytoplasms of ciliated epithelial cells in specimens with Carnoy's fluid fixation. No immunopositive reactions were detected in the negative control specimens with either fixation when TPBS was used instead of primary antibodies. The individual immunopositivities described above in the results section from specimens with Carnoy's fluid fixation were estimated by subtracting the immunopositivities in the negative controls.

\section{DISCUSSION}

Laboratory rodents usually live in contact with their feces in a rearing environment. Feces contain numerous Gram-negative bacteria derived from the alimentary tract [7]. Therefore, a large number of Gram-negative bacteria derived from dried feces probably adhere to the dust particles inhaled into the respiratory tract. The survival of bacteria is dependent on the moisture content in feces. Drying of feces condenses the concentration of various substances [15], suggesting that the condensation of bactericidal substances such as lysozyme and sPLA2 occurs in excreted feces, because of the presence of concentrated bactericidal substances in the luminal contents of the large intestine [49]. Almost all Escherichia coli, which is a Gram-negative bacteria, die immediately in dried feces [28]. Lipopolysaccharide, a constituent of Gram-negative bacteria, increases the expression of $\beta$-defensin 2 in human tracheobronchial epithelial cells in vitro [5]. Moreover, the inhaled large dust particles with bacteria or their constituents from dried feces are preferentially deposited in the cranial portion of the respiratory tract $[14,23,37]$. In the present study, secretory cells of $\beta$-defensin 1 and 2 were abundantly located in the nasal mucosa and decreased toward the terminal portion of the respiratory tract. Mucus and periciliary layers containing secreted $\beta$-defensin 1 and 2 were predominantly detected in the cranial portion of the respiratory tract (summarized in Fig. 8). Furthermore, the cranial portion of the human respiratory tract is a settlement site of not only Gram-positive but also Gram-negative bacteria under healthy conditions [17]. The defensins act bactericidally on Gramnegative bacteria rather than Gram-positive bacteria [20,21, 41]. Taken together, these facts show that secretory host defenses via $\beta$-defensin might be predominantly focused in the cranial portions of the respiratory tract.

In healthy humans, $\beta$-defensin-1 has been detected in broncho-alveolar lavage fluids [1,26, 41]. Beta-defensin 2 has also been detected in broncho-alveolar lavage fluids from healthy humans [26]. Beta-defensin 2 mRNA has been detected in the bronchus of humans [41] and granular alveolar cells of rats [27]. In the present study, a small number of secretory sources of $\beta$-defensin 1 and 2 were located in the extra-pulmonary bronchus. Moreover, only few granular alveolar cells were immunopositive for $\beta$-defensin 2 from the bronchiole to alveoli. Therefore, $\beta$-defensin 1 and 2 in broncho-alveolar lavage fluids are considered to be secreted from the extra-bronchial epithelium and alveolar granular cells. 


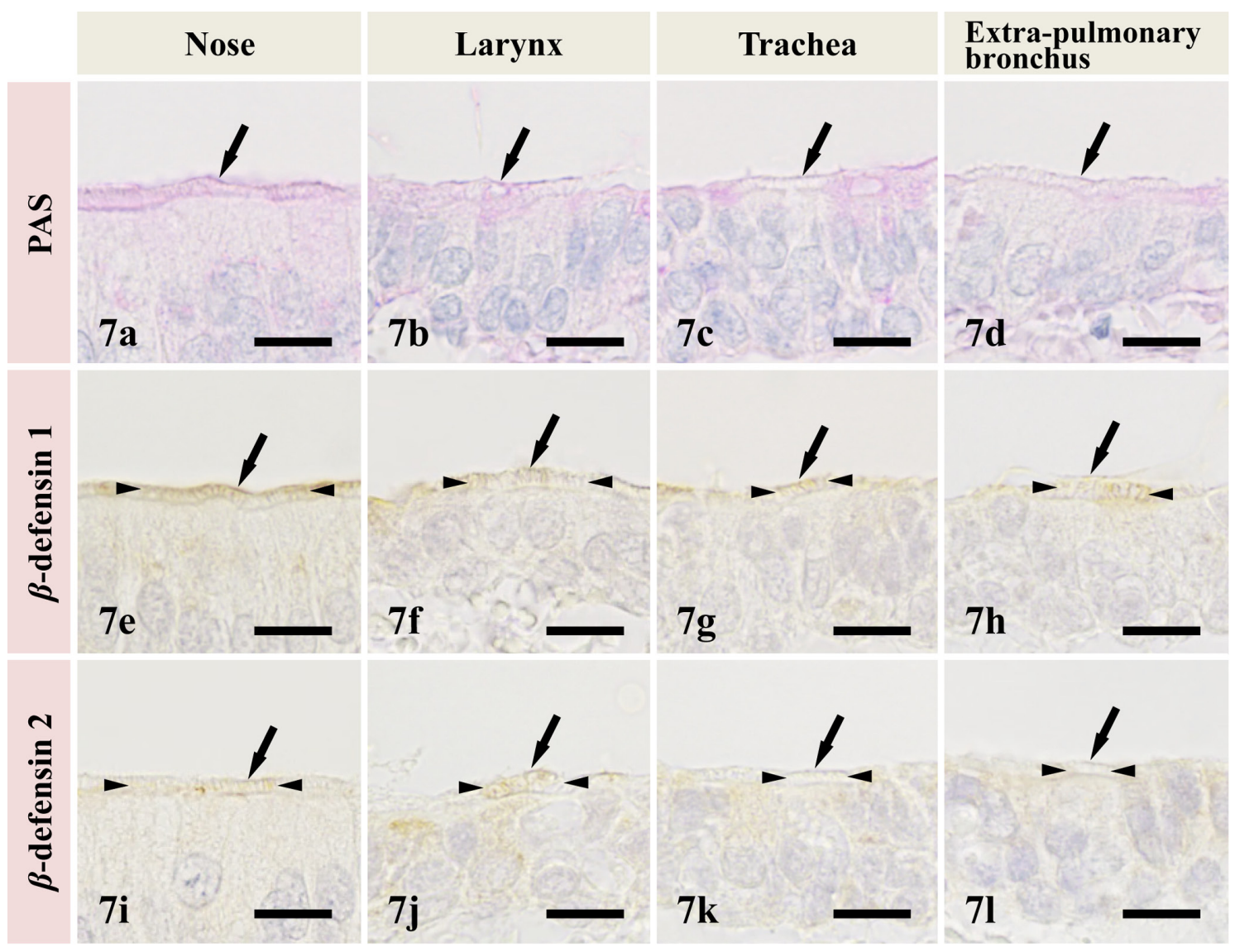

Fig. 7. Localization of $\beta$-defensin 1 and 2 in the mucus layer and the periciliary layer of Carnoy's fluid-fixed tissue. PAS-positive mucus layers (arrows in a-d) are visible on the periciliary layer of the nasal (a), laryngeal (b), tracheal (c) and extra-pulmonary bronchial (d) epithelia. The mucus layer (arrows in e-h) and the periciliary layer (between arrowheads in e-h) of nasal (e), laryngeal (f), tracheal (g) and extra-pulmonary bronchial (h) epithelia are immunopositive for $\beta$-defensin 1 . The mucus layer (arrows in $\mathrm{i}-\mathrm{l}$ ) and the periciliary layer (between arrowheads in i-l) are immunopositive for $\beta$-defensin 2 in the nasal (i) and laryngeal (j) epithelia, but not in the tracheal (k) and extra-pulmonary bronchial (l) epithelia. Bar=10 $\mu \mathrm{m}$.

In healthy humans, the broncho-alveolar lavage fluids of the caudal respiratory tract from the extra-pulmonary bronchus contain complement C3 [6]. C3 opsonizes exogenous substances to promote phagocytosis [38], and its derivative, C3a, directly kills Grampositive and -negative bacteria [33]. Surfactant protein A and D from Clara cells in the bronchiole and granular alveolar cells in the alveolus also opsonize inhaled substances $[16,36,45,46]$. In addition, alveolar macrophages and granular alveolar cells possess lysozyme in the alveoli [30]. In the present study, $\beta$-defensin 1 and 2 were the most poorly distributed from the intra-pulmonary bronchus to alveoli. Therefore, bactericidal substances other than $\beta$-defensins, such as C3 and surfactant proteins, probably form the first defense line against inhaled bacteria in the terminal portion of the respiratory tract, under healthy conditions.

The concentration of $\beta$-defensin 2 in broncho-alveolar lavage fluid is increased by bacterial stimulation in vivo in humans [25, $26,39]$. Moreover, lipopolysaccharides and lipopeptides from bacteria promote the expression of $\beta$-defensin 2 in tracheobronchial epithelial cells $[5,22]$. In infections and diseases, the concentrations of $\beta$-defensin 1 and 2 are increased in the nasal lavage fluid [8] and broncho-alveolar lavage fluid [32, 39]. Beta-defensin 2 mRNA is upregulated in the nasal epithelium in humans with chronic sinusitis [29]. In the present study, many secretory cells were immunonegative for $\beta$-defensin 1 and 2 throughout the respiratory tract under a healthy condition. Based on these findings, secretory cells, which were immunonegative for $\beta$-defensin 1 and 2 under healthy conditions, probably promote the production of these bactericidal substances in response to multiple bacterial stimulations or specific pathological conditions.

ACKNOWLEDGMENT. This work was supported by a JSPS KAKENHI Grant (No. 15K07766.)

\section{REFERENCES}

1. Agerberth, B., Grunewald, J., Castaños-Velez, E., Olsson, B., Jörnvall, H., Wigzell, H., Eklund, A. and Gudmundsson, G. H. 1999. Antibacterial components in bronchoalveolar lavage fluid from healthy individuals and sarcoidosis patients. Am. J. Respir. Crit. Care Med. 160: $283-290$. [Medline] [CrossRef] 


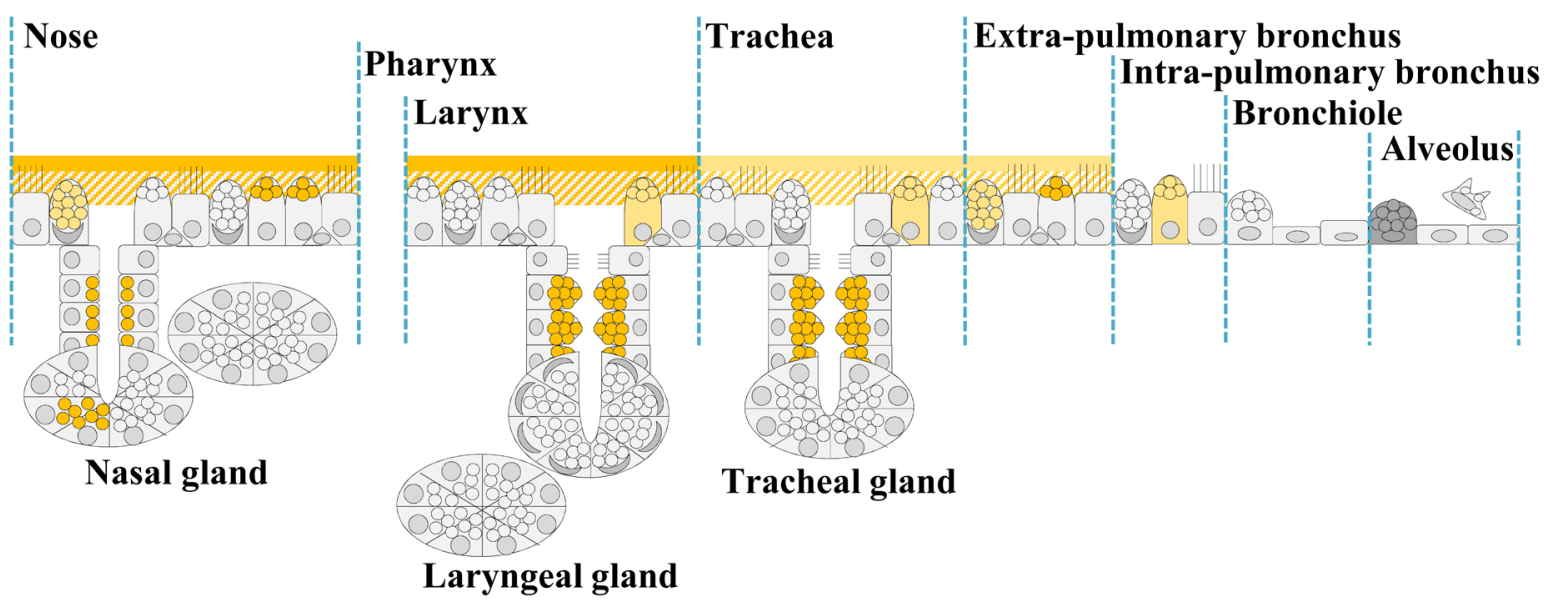

Fig. 8. Schema of the distribution of secretory cells of $\beta$-defensin 1 and 2 in the respiratory tract of healthy rats. Cells with orange granules represent secretory cells of both $\beta$-defensin 1 and 2, and those with pale orange granules represent secretory cells immunopositive for only $\beta$-defensin 1 . The orange band and orange-striped band represent both $\beta$-defensin 1- and 2-immunopositive mucus layer and periciliary layer on the epithelium, respectively. The pale orange band and pale orange-striped band represent only $\beta$-defensin 1 -immunopositive mucus layer and periciliary layer on the epithelium, respectively. The pale orange cells represent the rare cells positive for $\beta$-defensin 1 and 2 in laryngeal, tracheal and intra-pulmonary bronchial epithelia. The gray cell is the rare $\beta$-defensin 2-positive granular alveolar cells in the alveolar epithelium.

2. Aho, H. J., Grénman, R., Sipilä, J., Peuravuori, H., Hartikainen, J. and Nevalainen, T. J. 1997. Group II phospholipase A2 in nasal fluid, mucosa and paranasal sinuses. Acta Otolaryngol. 117: 860-863. [Medline] [CrossRef]

3. Bals, R., Goldman, M. J. and Wilson, J. M. 1998. Mouse $\beta$-defensin 1 is a salt-sensitive antimicrobial peptide present in epithelia of the lung and urogenital tract. Infect. Immun. 66: 1225-1232. [Medline]

4. Baricelli, J., Rocafull, M. A., Vázquez, D., Bastidas, B., Báez-Ramirez, E. and Thomas, L. E. 2015. $\beta$-defensin-2 in breast milk displays a broad antimicrobial activity against pathogenic bacteria. J. Pediatr. (Rio J.) 91: 36-43. [Medline] [CrossRef]

5. Becker, M. N., Diamond, G., Verghese, M. W. and Randell, S. H. 2000. CD14-dependent lipopolysaccharide-induced beta-defensin-2 expression in human tracheobronchial epithelium. J. Biol. Chem. 275: 29731-29736. [Medline] [CrossRef]

6. Bolger, M. S., Ross, D. S., Jiang, H., Frank, M. M., Ghio, A. J., Schwartz, D. A. and Wright, J. R. 2007. Complement levels and activity in the normal and LPS-injured lung. Am. J. Physiol. Lung Cell. Mol. Physiol. 292: L748-L759. [Medline] [CrossRef]

7. Brooks, S. P. J., McAllister, M., Sandoz, M. and Kalmokoff, M. L. 2003. Culture-independent phylogenetic analysis of the faecal flora of the rat. Can. J. Microbiol. 49: 589-601. [Medline] [CrossRef]

8. Carothers, D. G., Graham, S. M., Jia, H. P., Ackermann, M. R., Tack, B. F. and McCray, P. B. Jr. 2001. Production of $\beta$-defensin antimicrobial peptides by maxillary sinus mucosa. Am. J. Rhinol. 15: 175-179. [Medline] [CrossRef]

9. Casado, B., Pannell, L. K., Iadarola, P. and Baraniuk, J. N. 2005. Identification of human nasal mucous proteins using proteomics. Proteomics 5: 2949-2959. [Medline] [CrossRef]

10. Chen, J., Ryu, S., Gharib, S. A., Goodlett, D. R. and Schnapp, L. M. 2008. Exploration of the normal human bronchoalveolar lavage fluid proteome. Proteomics Clin. Appl. 2: 585-595. [Medline] [CrossRef]

11. Cole, A. M., Dewan, P. and Ganz, T. 1999. Innate antimicrobial activity of nasal secretions. Infect. Immun. 67: 3267-3275. [Medline]

12. Feng, Z., Jiang, B., Chandra, J., Ghannoum, M., Nelson, S. and Weinberg, A. 2005. Human beta-defensins: differential activity against candidal species and regulation by Candida albicans. J. Dent. Res. 84: 445-450. [Medline] [CrossRef]

13. Ferrari, R., Callerio, C. and Podio, G. 1959. Antiviral activity of lysozyme. Nature 183: 548. [Medline] [CrossRef]

14. Fry, F. A. and Black, A. 1973. Regional deposition and clearance of particles in the human nose. J. Aerosol Sci. 4: 113-124. [CrossRef]

15. Garfield, L. M. and Walker, M. J. 2008. Water potential changes in faecal matter and Escherichia coli survival. J. Appl. Microbiol. 105: 1009-1016. [Medline] [CrossRef]

16. Gaynor, C. D., McCormack, F. X., Voelker, D. R., McGowan, S. E. and Schlesinger, L. S. 1995. Pulmonary surfactant protein A mediates enhanced phagocytosis of Mycobacterium tuberculosis by a direct interaction with human macrophages. J. Immunol. 155: 5343-5351. [Medline]

17. Glück, U. and Gebbers, J. O. 2000. The nose as bacterial reservoir: important differences between the vestibule and cavity. Laryngoscope 110: 426-428. [Medline] [CrossRef]

18. Grönroos, J. O., Laine, V. J. O., Janssen, M. J. W., Egmond, M. R. and Nevalainen, T. J. 2001. Bactericidal properties of group IIA and group V phospholipases A J. Immunol. 166: 4029-4034. [Medline] [CrossRef]

19. Harada, R. N. and Repine, J. E. 1985. Pulmonary host defense mechanisms. Chest 87: 247-252. [Medline] [CrossRef]

20. Harder, J., Bartels, J., Christophers, E. and Schröder, J. M. 1997. A peptide antibiotic from human skin. Nature 387: 861. [Medline] [CrossRef]

21. Harder, J., Meyer-Hoffert, U., Teran, L. M., Schwichtenberg, L., Bartels, J., Maune, S. and Schröder, J. M. 2000. Mucoid Pseudomonas aeruginosa, TNF- $\alpha$, and IL-1 $\beta$, but not IL-6, induce human $\beta$-defensin-2 in respiratory epithelia. Am. J. Respir. Cell Mol. Biol. 22: 714-721. [Medline] [CrossRef]

22. Hertz, C. J., Wu, Q., Porter, E. M., Zhang, Y. J., Weismüller, K. H., Godowski, P. J., Ganz, T., Randell, S. H. and Modlin, R. L. 2003. Activation of Toll-like receptor 2 on human tracheobronchial epithelial cells induces the antimicrobial peptide human $\beta$ defensin-2. J. Immunol. 171: 6820-6826. [Medline] [CrossRef]

23. Heyder, J., Gebhart, J., Rudolf, G., Schiller, C. F. and Stahlhofen, W. 1986. Deposition of particles in the human respiratory tract in the size range 0.005-15 $\mu \mathrm{m}$. J. Aerosol Sci. 17: 811-825. [CrossRef]

24. Hill, C. P., Yee, J., Selsted, M. E. and Eisenberg, D. 1991. Crystal structure of defensin HNP-3, an amphiphilic dimer: mechanisms of membrane permeabilization. Science 251: 1481-1485. [Medline] [CrossRef] 
25. Hiratsuka, T., Nakazato, M., Date, Y., Ashitani, J., Minematsu, T., Chino, N. and Matsukura, S. 1998. Identification of human $\beta$-defensin-2 in respiratory tract and plasma and its increase in bacterial pneumonia. Biochem. Biophys. Res. Commun. 249: 943-947. [Medline] [CrossRef]

26. Hiratsuka, T., Mukae, H., Iiboshi, H., Ashitani, J., Nabeshima, K., Minematsu, T., Chino, N., Ihi, T., Kohno, S. and Nakazato, M. 2003. Increased concentrations of human $\beta$-defensins in plasma and bronchoalveolar lavage fluid of patients with diffuse panbronchiolitis. Thorax 58: $425-430$. [Medline] [CrossRef]

27. Jia, H. P., Mills, J. N., Barahmand-Pour, F., Nishimura, D., Mallampali, R. K., Wang, G., Wiles, K., Tack, B. F., Bevins, C. L. and McCray, P. B. Jr. 1999. Molecular cloning and characterization of rat genes encoding homologues of human $\beta$-defensins. Infect. Immun. 67: 4827-4833. [Medline]

28. Kudva, I. T., Blanch, K. and Hovde, C. J. 1998. Analysis of Escherichia coli O157:H7 survival in ovine or bovine manure and manure slurry. Appl. Environ. Microbiol. 64: 3166-3174. [Medline]

29. Lee, S. H., Kim, J. E., Lim, H. H., Lee, H. M. and Choi, J. O. 2002. Antimicrobial defensin peptides of the human nasal mucosa. Ann. Otol. Rhinol. Laryngol. 111: 135-141. [Medline] [CrossRef]

30. Masuda, N., Mantani, Y., Yoshitomi, C., Yuasa, H., Nishida, M., Arai, M., Kawano, J., Yokoyama, T., Hoshi, N. and Kitagawa, H. 2017. Immunohistochemical study on the secretory host defense system with lysozyme and secretory phospholipase A2 throughout rat respiratory tract. $J$. Vet. Med. Sci. 80: 10.1292/jvms.17-0503. [Medline]

31. Matsui, H., Randell, S. H., Peretti, S. W., Davis, C. W. and Boucher, R. C. 1998. Coordinated clearance of periciliary liquid and mucus from airway surfaces. J. Clin. Invest. 102: 1125-1131. [Medline] [CrossRef]

32. Mukae, H., Ishimoto, H., Yanagi, S., Ishii, H., Nakayama, S., Ashitani, J., Nakazato, M. and Kohno, S. 2007. Elevated BALF concentrations of $\alpha$ - and $\beta$-defensins in patients with pulmonary alveolar proteinosis. Respir. Med. 101: 715-721. [Medline] [CrossRef]

33. Nordahl, E. A., Rydengård, V., Nyberg, P., Nitsche, D. P., Mörgelin, M., Malmsten, M., Björck, L. and Schmidtchen, A. 2004. Activation of the complement system generates antibacterial peptides. Proc. Natl. Acad. Sci. U.S.A. 101: 16879-16884. [Medline] [CrossRef]

34. Patil, A. A., Cai, Y., Sang, Y., Blecha, F. and Zhang, G. 2005. Cross-species analysis of the mammalian $\beta$-defensin gene family: presence of syntenic gene clusters and preferential expression in the male reproductive tract. Physiol. Genomics 23: 5-17. [Medline] [CrossRef]

35. Peterson, R. G. and Hartsell, S. E. 1955. The lysozyme spectrum of the gram-negative bacteria. J. Infect. Dis. 96: 75-81. [Medline] [CrossRef]

36. Phelps, D. S. and Floros, J. 1991. Localization of pulmonary surfactant proteins using immunohistochemistry and tissue in situ hybridization. Exp. Lung Res. 17: 985-995. [Medline] [CrossRef]

37. Raabe, O. G., Al-Bayati, M. A., Teague, S. V. and Rasolt, A. 1988. Regional deposition of inhaled monodisperse coarse and fine aerosol particles in small laboratory animals. Ann. Occup. Hyg. 32: 53-63.

38. Ricklin, D., Reis, E. S., Mastellos, D. C., Gros, P. and Lambris, J. D. 2016. Complement component C3 - The "Swiss Army Knife” of innate immunity and host defense. Immunol. Rev. 274: 33-58. [Medline] [CrossRef]

39. Schaller-Bals, S., Schulze, A. and Bals, R. 2002. Increased levels of antimicrobial peptides in tracheal aspirates of newborn infants during infection. Am. J. Respir. Crit. Care Med. 165: 992-995. [Medline] [CrossRef]

40. Semple, C. A., Gautier, P., Taylor, K. and Dorin, J. R. 2006. The changing of the guard: Molecular diversity and rapid evolution of $\beta$-defensins. Mol. Divers. 10: 575-584. [Medline] [CrossRef]

41. Singh, P. K., Jia, H. P., Wiles, K., Hesselberth, J., Liu, L., Conway, B. A., Greenberg, E. P., Valore, E. V., Welsh, M. J., Ganz, T., Tack, B. F. and McCray, P. B. Jr. 1998. Production of $\beta$-defensins by human airway epithelia. Proc. Natl. Acad. Sci. U.S.A. 95: 14961-14966. [Medline] [CrossRef]

42. Snipes, M. B. 1989. Long-term retention and clearance of particles inhaled by mammalian species. Crit. Rev. Toxicol. 20: 175-211. [Medline] [CrossRef]

43. Sun, L., Finnegan, C. M., Kish-Catalone, T., Blumenthal, R., Garzino-Demo, P., La Terra Maggiore, G. M., Berrone, S., Kleinman, C., Wu, Z., Abdelwahab, S., Lu, W. and Garzino-Demo, A. 2005. Human $\beta$-defensins suppress human immunodeficiency virus infection: potential role in mucosal protection. J. Virol. 79: 14318-14329. [Medline] [CrossRef]

44. Travis, S. M., Singh, P. K. and Welsh, M. J. 2001. Antimicrobial peptides and proteins in the innate defense of the airway surface. Curr. Opin. Immunol. 13: 89-95. [Medline] [CrossRef]

45. van Iwaarden, J. F., van Strijp, J. A. G., Ebskamp, M. J. M., Welmers, A. C., Verhoef, J. and van Golde, L. M. G. 1991. Surfactant protein A is opsonin in phagocytosis of herpes simplex virus type 1 by rat alveolar macrophages. Am. J. Physiol. 261: L204-L209. [Medline]

46. Voorhout, W. F., Veenendaal, T., Kuroki, Y., Ogasawara, Y., van Golde, L. M. and Geuze, H. J. 1992. Immunocytochemical localization of surfactant protein D (SP-D) in type II cells, Clara cells, and alveolar macrophages of rat lung. J. Histochem. Cytochem. 40: 1589-1597. [Medline] [CrossRef]

47. Woods, C. M., Hooper, D. N., Ooi, E. H., Tan, L. W. and Carney, A. S. 2011. Human lysozyme has fungicidal activity against nasal fungi. Am. J. Rhinol. Allergy 25: 236-240. [Medline] [CrossRef]

48. Yao, M. and Mainelis, G. 2007. Use of portable microbial samplers for estimating inhalation exposure to viable biological agents. J. Expo. Sci. Environ. Epidemiol. 17: 31-38. [Medline] [CrossRef]

49. Yokoo, Y., Miyata, H., Udayanga, K. G. S., Qi, W. M., Takahara, E., Yokoyama, T., Kawano, J., Hoshi, N. and Kitagawa, H. 2011. Immunohistochemical study on the secretory host defense system of bactericidal peptides in rat digestive organs. J. Vet. Med. Sci. 73: $217-225$. [Medline] [CrossRef]

50. Yoneda, K. 1976. Mucous blanket of rat bronchus: an ultrastructural study. Am. Rev. Respir. Dis. 114: 837-842. [Medline] 